\title{
STUDI EPIDEMIOLOGI DENGAN PENDEKATAN ANALISIS SPASIAL TERHADAP FAKTOR-FAKTOR RISIKO PENYAKIT INFEKSI SALURAN PERNAPASAN AKUT (ISPA) PADA ANAK DI KECAMATAN SRAGEN
}

\author{
Wiwik Setyaningsih, Dodiet Aditya Setyawan, Ari Sarwanto \\ Kementerian Kesehatan Politeknik Kesehatan Surakarta Jurusan Terapi Wicara
}

\begin{abstract}
Geographic Information System (GIS), acute respiratory infection in children. Manifestation quality healthy environment is an essential part that can not be abandoned in the field of health. Air as an important environmental component in the life of mankind, should be maintained and enhanced so as to provide carrying capacity for a higher quality of human life. Today the disease based on environment is still a health problem that is dominant in the middle - the middle of the Indonesian people. This is reflected in the high number of events and visits patients with several diseases to the center - the center of health care such as diarrhea, malaria, dengue hemorrhagic fever (DHF), tuberculosis, acute respiratory infections, skin diseases, worm infection as well as health problems or poisoning from chemicals and pesticides (Depkes RI, 2002). From these diseases, Acute Respiratory Infections still contributed the most to the morbidity, and until now the disease is still a public health problem that is the main, both in developed countries and countries emerging (Wahyudi, 2004). This study design is modeling Case Control using Geographic Information System (GIS). Purposive sample taken with the number of 80 respondents. Data were analyzed using Chi Square, Multiple Logistic Regression and spatial analysis using overlay function and Buffering. Results show risk factors are shown to be significantly associated with the incidence of respiratory disease in children in the district of Sragen is the density of the household $(O R=0.075,95 \% C I=0019-0293$, with a value of $p=$ $0.000)$; distance of residence to the highway within a radius of $\leq 250$ meters $(O R$ $=0334,95 \% C I=0118$ to 0949, with a value of $p=0.040$ ).
\end{abstract}

Keywords: Geographic Information System (GIS), acute respiratory infection in children.

Abstrak: Sistem Informasi Geografis (SIG), ISPA pada Anak. Perwujudan kualitas lingkungan yang sehat merupakan bagian pokok yang tidak bisa ditinggalkan begitu saja di bidang kesehatan. Dewasa ini penyakit berbasis lingkungan masih merupakan masalah kesehatan yang dominan di tengah tengah masyarakat Indonesia. Dari berbagai penyakit tersebut, Infeksi Saluran Pernapasan Akut (ISPA) masih memberikan andil yang terbesar terhadap angka kesakitan, dan hingga saat ini penyakit tersebut masih merupakan masalah kesehatan masyarakat yang utama, baik di Negara maju maupun Negara yang sedang berkembang (Wahyudi, 2004). Desain penelitian ini adalah Case Control dengan menggunakan pemodelan Sistem Informasi Geografis (SIG). Sampel diambil secara Purposive dengan jumlah 80 responden. Data dianalisis dengan uji Chi Square, Regresi Logistik Ganda dan analisis spasial menggunakan fungsi 
overlay dan Buffering. Hasil Penelitian menunjukkan faktor-faktor risiko yang terbukti secara signifikan berhubungan dengan kejadian penyakit ISPA pada anak di kecamatan Sragen adalah kepadatan penghuni rumah $(\mathrm{OR}=0.075,95 \% \mathrm{CI}=$ $0.019-0.293$, dengan nilai $p=0.000)$; jarak tempat tinggal dengan jalan raya dalam radius $\leq 250$ meter $(\mathrm{OR}=0.334,95 \% \mathrm{CI}=0.118-0.949$, dengan nilai $p=$ 0.040).

Kata Kunci: Sistem Informasi Geografis (SIG), ISPA pada Anak

\section{PENDAHULUAN.}

Perwujudan kualitas lingkungan yang sehat merupakan bagian pokok yang tidak bisa ditinggalkan begitu saja di bidang kesehatan. Udara sebagai komponen lingkungan yang penting dalam kehidupan umat manusia, perlu dipelihara dan ditingkatkan kualitasnya sehingga mampu memberikan daya dukung bagi kehidupan manusia yang lebih berkualitas. Dewasa ini penyakit berbasis lingkungan masih merupakan masalah kesehatan yang dominan di tengah - tengah masyarakat Indonesia. Hal ini tercermin pada tingginya angka kejadian dan kunjungan penderita beberapa penyakit tersebut ke pusat pusat pelayanan kesehatan seperti penyakit diare, malaria, demam berdarah dengue (DBD), Tuberculosis, infeksi saluran pernapasan akut (ISPA), penyakit kulit, kecacingan serta gangguan kesehatan atau keracunan karena bahan kimia dan pestisida (Depkes RI, 2002).

Dari berbagai penyakit tersebut, Infeksi Saluran Pernapasan Akut (ISPA) masih memberikan andil yang terbesar terhadap angka kesakitan, dan hingga saat ini penyakit tersebut masih merupakan masalah kesehatan masyarakat yang utama, baik di Negara maju maupun Negara yang sedang berkembang (Wahyudi, 2004). Penyakit Infeksi Saluran Pernapasan Akut (ISPA) merupakan penyakit terbanyak yang diderita oleh anak - anak, baik di
Negara yang sedang berkembang maupun Negara maju. Penyakit Infeksi Saluran Pernapasan Akut (ISPA) khususnya pneumonia masih merupakan penyakit utama penyebab kesakitan dan kematian pada bayi dan balita. Untuk itu dalam Millenium Development Goals (MDG's) telah dicanangkan komitmen global bidang kesehatan yang akan menurunkan 2/3 angka kematian balita pada rentang waktu antara tahun 1990 2015. Kemudian dalam Undang undang nomor 25 tahun 2004, tentang Rencana Pembangunan Jangka Menengah Nasional (RPJMN) 2004 2009, dimana di dalamnya juga disebutkan bahwa salah satu sasaran yang akan dicapai adalah menurunkan angka kematian balita dari 35 per 1000 menjadi 26 per 1000 (Depkes RI, 2005). Penelitian ditujukan untuk mengetahui gambaran distribusi dan faktor-faktor risiko yang berhubungan dengan kejadian penyakit ISPA pada anak di kecamatan Sragen dengan pemodelan Sistem Informasi Geografis (SIG).

\section{METODE PENELITIAN}

Desain penelitian ini adalah Analitik Observasional dengan pendekatan Case Control menggunakan pemodelan Sistem Informasi Geografis (SIG) dan analisis spasial untuk mendapatkan gambaran distribusi spasial kasus ISPA serta hubungan 
faktor-faktor risiko kejadian penyakit ISPA di Kecamatan Sragen.

Sampel diambil secara Purposive dengan jumlah 80 responden.Data dianalisis secara bivariat dengan uji $C h i$ Square, analisis multivariat dengan Regresi Logistik Ganda dan analisis spasial menggunakan fungsi overlay dan Buffering melalui pemodelan Sistem Informasi Geografis (SIG) menggunakan software ArcGIS.

\section{HASIL PENELITIAN}

Distribusi frekuensi jenis kelamin responden pada kelompok kasus maupun kontrol disajikan pada tabel 1 berikut ini:

\section{Tabel 1}

Distribusi Frekuensi Responden Menurut Jenis Kelamin

\begin{tabular}{ccccc}
\hline Jenis & \multicolumn{2}{c}{ Kasus } & \multicolumn{2}{c}{ Kontrol } \\
\cline { 2 - 5 } Kelamin & $\mathrm{n}$ & $\%$ & $\mathrm{n}$ & $\%$ \\
\hline Laki-laki & 25 & $62,5 \%$ & 23 & $57,5 \%$ \\
Perempuan & 15 & $37,5 \%$ & 17 & $42,5 \%$ \\
\hline Jumlah & 40 & $100 \%$ & 40 & $100 \%$
\end{tabular}

Pada tabel 1 tersebut memberikan gambaran bahwa sebagian besar responden pada kelompok kasus adalah berjenis kelamin laki-laki, yaitu sejumlah 25 responden atau sebesar $62,5 \%$. Demikian juga pada kelompok kontrol jumlah dan frekuensinya sebagian besar adalah laki-laki yaitu sebesar 57,5\%.

Distribusi frekuensi variabel penelitian disajikan dalam tabel 2 berikut ini:
Tabel 2

Distribusi Frekuensi Variabel Penelitian

\begin{tabular}{|c|c|c|c|c|}
\hline \multirow[b]{2}{*}{ Variabel } & \multicolumn{2}{|c|}{ Kasus } & \multicolumn{2}{|c|}{ Kontrol } \\
\hline & $\begin{array}{c}\mathrm{n}= \\
40\end{array}$ & $\%$ & $\begin{array}{c}\mathrm{n}= \\
40\end{array}$ & $\%$ \\
\hline \multicolumn{5}{|l|}{ Jenis Kelamin } \\
\hline Laki-laki & 25 & 62,5 & 23 & 57,5 \\
\hline Perempuan & 15 & 37,5 & 17 & 42,5 \\
\hline \multicolumn{5}{|l|}{ Kepadatan } \\
\hline \multicolumn{5}{|l|}{ Penghuni } \\
\hline \multicolumn{5}{|l|}{ Rumah } \\
\hline Padat & 37 & 92,5 & 19 & 47,5 \\
\hline Tidak Padat & 3 & 7,5 & 21 & 52,5 \\
\hline Paparan Asap & & & & \\
\hline Rokok dalam & & & & \\
\hline \multicolumn{5}{|l|}{ Keluarga } \\
\hline Ada & 15 & 37,5 & 13 & 32,5 \\
\hline Tidak Ada & 25 & 62,5 & 27 & 67,5 \\
\hline $\begin{array}{lr}\text { Jarak } & \text { Rumah } \\
\text { dengan } & \text { Jalan }\end{array}$ & & & & \\
\hline \multicolumn{5}{|l|}{ Raya } \\
\hline Dekat $\quad(\leq 250$ & 25 & 62,5 & 14 & 35 \\
\hline  & 15 & 37,5 & 26 & 65 \\
\hline
\end{tabular}
dapat diketahui bahwa responden pada kelompok kasus yang tinggal dalam rumah dengan tingkat kepadatan penghuni yang padat sejumlah 37 orang atau sebesar 92,5\%. Sedangkan pada kelompok kontrol, yang tinggal dalam rumah dengan tingkat kepadatan penghuni yang tinggi atau padat adalah sejumlah 19 responden atau sebesar $47,5 \%$.

Gambaran distribusi frekuensi responden berdasarkan paparan asap rokok dalam rumah akibat adanya anggota keluarga yang merokok pada kelompok kasus dan kelompok kontrol yang disajikan dalam Tabel 2 tersebut di atas menunjukkan bahwa sebagian besar responden tidak terapapar asap rokok. Sedangkan responden yang terapapar asap rokok pada kelompok kasus hanya $37,5 \%$ dan kelompok kontrol sebesar $32,5 \%$. 
Gambaran distribusi frekuensi responden berdasarkan jarak tempat tinggal dengan jalan raya baik pada kelompok kasus menunjukkan bahwa sebagian besar responden tinggal di daerah yang dekat dengan jalan raya, yaitu sebesar $62,5 \%$.

Selain disajikan dalam bentuk Tabel Distribusi Frekuensi, distribusi atau persebaran kasus ISPA pada anak dalam penelitian ini juga disajikan secara spasial dalam bentuk peta. Hal ini dimaksudkan untuk memberikan gambaran distribusi spasial kasus ISPA pada anak di kecamatan Sragen.

Distribusi spasial kasus ISPA pada anak di kecamatan Sragen yaitu sejumlah 40 kasus yang dipetakan, terbanyak terdapat di kelurahan Sragen Wetan sebanyak 11 kasus, kelurahan Nglorog 9 kasus, kelurahan Sragen Tengah 7 kasus dan kelurahan Sragen Kulon sebayak 5 kasus.

Sedangkan desa atau kelurahan dengan jumlah kasus yang digunakan dalam penelitian ini yang paling sedikit adalah di desa Kedungupit, yaitu hanya ada 1 kasus. Peta distribusi atau persebaran kasus ISPA pada anak di kecamatan Sragen tersebut dapat dilihat pada gambar 1 .

Analisis dan pemodelan spasial dilakukan dengan fungsi Buffering dan Overlay untuk membuat pemetaan distribusi kejadian ISPA dengan software ArcGIS 9.3. Hasil analisis ini dapat memberikan penjelasan kemungkinan kejadian ISPA tersebut akan mengikuti pola sebaran spasial tertentu atau tidak. Buffering dilakukan terhadap jalan raya atau jalan utama yang melintas di sepanjang kecamatan Sragen pada jarak 250 meter.

Penentuan jarak tersebut didasarkan pada asumsi tingkat keterpaparan terhadap polusi udara di sekitar jalan raya, dimana pada jarak $\leq 250$ meter merupakan daerah dengan paparan yang tinggi terhadap polusi udara oleh karena aktivitas kendaraan bermotor di sekitar jalan raya. Sedangkan pada jarak >250 meter merupakan daerah yang tidak ada paparan terhadap polusi udara jalan raya. (Nuvolone, et al.,2011).

Analisis spasial dengan fungsi overlay dilakukan untuk melihat atau memprediksi daerah yang mempunyai risiko tinggi untuk terjadinya serangan ISPA pada anak di kecamatan Sragen. Overlay dilakukan terhadap peta distribusi kasus ISPA dan peta buffering terhadap jalan raya pada jarak hingga 250 meter.

Berdasarkan hasil analisis spasial dengan fungsi Overlay pada peta buffering 250 meter terhadap jalan raya dengan peta sebaran kasus ISPA pada anak di kecamatan Sragen, menunjukkan bahwa sebagian besar titik koordinat atau lokasi anak penderita ISPA yaitu sejumlah 25 atau sebesar $62,5 \%$ berada pada wilayah buffer tersebut. Sedangkan sejumlah 15 responden atau sebesar $37,5 \%$ lokasi titik koordinatnya berada di luar wilayah buffer 250 meter dari jalan raya.

Peta Buffering dan Overlay distribusi kasus ISPA pada anak di wilayah kecamatan Sragen tersebut dapat dilihat pada gambar 2 dan 3.

Analisis bivariat dilakukan untuk mengetahui hubungan antara variabel bebas dengan variabel terikat. Hasil analisis Bivariat dengan menggunakan uji Chi Square adalah sebagai berikut: 
Tabel 3

Hasil Analisis Bivariat

\begin{tabular}{|c|c|c|c|c|}
\hline \multirow[b]{2}{*}{ Variabel } & \multicolumn{2}{|c|}{ Kejadian ISPA } & \multirow[b]{2}{*}{$P$} & \multirow[b]{2}{*}{ OR } \\
\hline & KASUS & $\begin{array}{l}\text { KONTRO } \\
\text { L }\end{array}$ & & \\
\hline Jenis Kelamin & $(n=40)$ & $(n=40)$ & \multirow[b]{3}{*}{0.648} & \multirow[b]{3}{*}{0.81} \\
\hline - $\quad$ Laki-laki & 25 & 23 & & \\
\hline - Perempuan & 15 & 17 & & \\
\hline \multicolumn{5}{|c|}{ Kepadatan Penghuni Rumah } \\
\hline - Padat & 37 & 21 & \multirow{2}{*}{0.000} & \multirow{2}{*}{13.6} \\
\hline - $\quad$ Tidak & 3 & 19 & & \\
\hline \multicolumn{5}{|c|}{ Paparan Asap Rokok } \\
\hline - Ada & 15 & 13 & \multirow{2}{*}{0.639} & \multirow{2}{*}{1.25} \\
\hline - $\quad$ Tidak Ada & 25 & 27 & & \\
\hline \multicolumn{5}{|c|}{ Jarak Rumah dengan Jalan Raya } \\
\hline - Dekat & 25 & 14 & \multirow{2}{*}{0.014} & \multirow{2}{*}{3.09} \\
\hline - Jauh & 15 & 16 & & \\
\hline
\end{tabular}

Berdasarkan hasil analisis bivariat tersebut, maka hubungan antar variabel dapat dijelaskan sebagai berikut:

\section{Hubungan antara Jenis Kelamin dengan Kasus ISPA pada Anak.}

Dari hasil analisis bivariat dengan uji Chi Square pada Tabel 3 diperoleh nilai $p$ sebesar 0,648. Hal tersebut berarti secara statistik tidak terdapat hubungan yang bermakna antara jenis kelamin dengan kejadian ISPA pada anak.

Sedangkan parameter kekuatan hubungan didapatkan Odds Ratio (OR) sebesar 0.8 dengan Confidence Interval $95 \%$ antara 0.33 - 1.99. Hal ini berarti, anak laki-laki mempunyai kemungkinan 0.8 kali lebih besar untuk mengalami serangan ISPA dibandingkan dengan anak perempuan.

\section{Hubungan antara Kepadatan Penghuni Rumah dengan Kasus ISPA pada Anak.}

Berdasarkan hasil analisis bivariat dengan uji Chi Square pada Tabel 3 tersebut di atas, diperoleh nilai $p$ sebesar 0,000. Hal menunjukkan bahwa secara statistik terdapat hubungan yang bermakna antara kepadatan penghuni rumah dengan kejadian ISPA pada anak.
Sedangkan parameter kekuatan hubungan didapatkan nilai Odds Ratio (OR) sebesar 13.63 dengan Confidence Interval 95\% antara 3.60-51.55. Hal ini berarti bahwa anak yang tinggal dalam rumah dengan tingkat kepadatan penghuni rumah yang melebihi batas normal mempunyai kemungkinan 13.63 kali lebih besar untuk mengalami serangan ISPA dibandingkan dengan anak yang tinggal dalam rumah dengan tingkat kepadatan yang normal.

\section{Hubungan antara Paparan Asap Rokok dalam Rumah dengan Kasus ISPA pada Anak.}

Dari hasil analisis bivariat dengan uji Chi Square pada Tabel 3 diperoleh nilai $p$ sebesar 0,639. Hal tersebut berarti secara statistik tidak terdapat hubungan yang bermakna antara paparan asap rokok dalam rumah yang disebabkan oleh adanya kebiasaan merokok anggota keluarga dengan kejadian ISPA pada anak.

Sedangkan parameter kekuatan hubungan didapatkan Odds Ratio (OR) sebesar 1.25 dengan Confidence Interval $95 \%$ antara 0.49 - 3.12. Hal ini berarti bahwa anak yang terpapar asap rokok, mempunyai kemungkinan 1.25 kali lebih besar untuk mengalami serangan ISPA dibandingkan dengan anak yang dalam keluarganya tidak ada paparan asap rokok.

\section{Hubungan antara Jarak Tempat Tinggal dengan Jalan Raya dengan Kasus ISPA pada Anak.}

Berdasarkan hasil analisis bivariat dengan uji Chi Square pada Tabel 3 di atas, diperoleh nilai p sebesar 0,014 . Hal tersebut menunjukkan bahwa secara statistik terdapat hubungan yang bermakna antara jarak tempat tinggal 
dengan jalan raya dengan kejadian ISPA pada anak di kecamatan Sragen.

Sedangkan parameter kekuatan hubungan didapatkan nilai Odds Ratio (OR) sebesar 3.09 dengan Confidence Interval $95 \%$ antara $1.24-7.70$. Hal ini berarti bahwa anak yang rumahnya dekat dengan jalan raya mempunyai kemungkinan 3.09 kali lebih besar untuk mengalami serangan ISPA dibandingkan dengan anak yang tempat tinggalnya jauh dengan jalan raya.

\section{Analisis Multivariat}

Adapun hasil analisis multivariat menggunakan uji Regresi Logistik Ganda dengan metode Enter terhadap variabel-variabel tersebut adalah sebagai berikut:

\section{Tabel 4}

\section{Hasil Analisis Multivariat}

\begin{tabular}{lccc}
\hline \multicolumn{1}{c}{ Variabel } & $p$ & OR & $95 \%$ CI \\
\hline $\begin{array}{l}\text { Kepadatan } \\
\text { Penghuni Rumah }\end{array}$ & 0.000 & $\mathbf{0 . 0 7 5}$ & $\begin{array}{c}0.019- \\
0.293\end{array}$ \\
$\begin{array}{l}\text { Jarak Tempat } \\
\text { Tinggal dengan }\end{array}$ & 0.040 & $\mathbf{0 . 3 3 4}$ & $\begin{array}{c}0.118- \\
0.949 \\
\text { Jalan Raya }\end{array}$ \\
Constant & 0.000 & $\mathbf{4 6 9 . 7}$ & -
\end{tabular}

\begin{tabular}{cccc}
\hline Pada & Tabel 4 tersebut
\end{tabular}
menunjukkan langkah dalam analisis multivariat terhadap variabel bebas dalam penelitian ini. Langkah tersebut hanya dilakukan satu kali karena variabel bebas yang memenuhi syarat untuk analisis multivariat hanya ada 2 variabel sehingga dengan satu langkah saja sudah diperoleh variabel dengan $p$ value lebih kecil dari 0.05 .

Berdasarkan hasil analisis multivariat tersebut menunjukkan bahwa variabel yang berpengaruh terhadap kejadian ISPA pada anak adalah kepadatan penghuni rumah dan jarak rumah atau tempat tinggal dari jalan raya. Hasil analisis tersebut didapatkan Odds Ratio (OR) dari variabel kepadatan penghuni rumah adalah 0.075 artinya anak yang tinggal dalam rumah dengan tingkat kepadatan penghuni rumah yang melebihi batas normal mempunyai kemungkinan 0.075 kali lebih besar untuk mengalami serangan ISPA dibandingkan dengan anak yang tinggal dalam rumah engan tingkat kepadatan yang normal.

Sedangkan Odds Ratio (OR) dari variabel jarak tempat tinggal dari jalan raya adalah 0.334 . Hal ini berarti bahwa anak yang rumahnya dekat dengan jalan raya mempunyai kemungkinan 0.334 kali lebih besar untuk mengalami serangan ISPA dibandingkan dengan anak yang tempat tinggalnya jauh dengan jalan raya.

Diantara kedua variabel tersebut, maka variabel yang paling dominan pengaruhnya terhadap kejadian ISPA pada anak adalah jarak tempat tinggal dengan jalan raya dengan $\mathrm{OR}=0,334$.

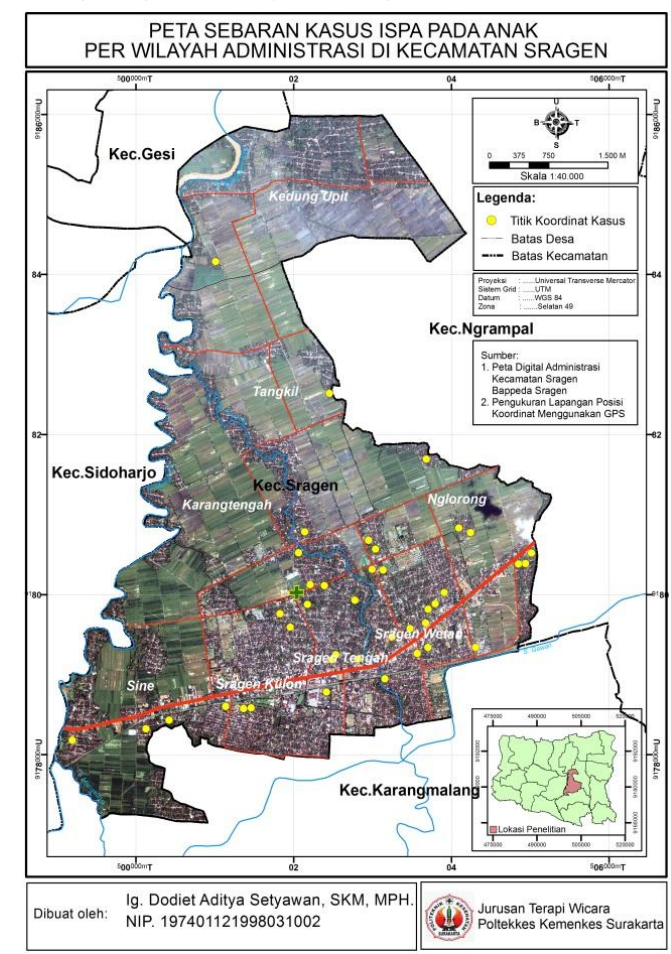

Gambar Peta di atas (Gambar 1) menunjukkan distribusi spasial kasus 
ISPA pada anak di kecamatan Sragen yaitu sejumlah 40 kasus yang dipetakan, terbanyak terdapat di kelurahan Sragen Wetan sebanyak 11 kasus, kelurahan Nglorog 9 kasus, kelurahan Sragen Tengah 7 kasus dan kelurahan Sragen Kulon sebayak 5 kasus.

Sedangkan desa atau kelurahan dengan jumlah kasus yang digunakan dalam penelitian ini yang paling sedikit adalah di desa Kedungupit, yaitu hanya ada 1 kasus.
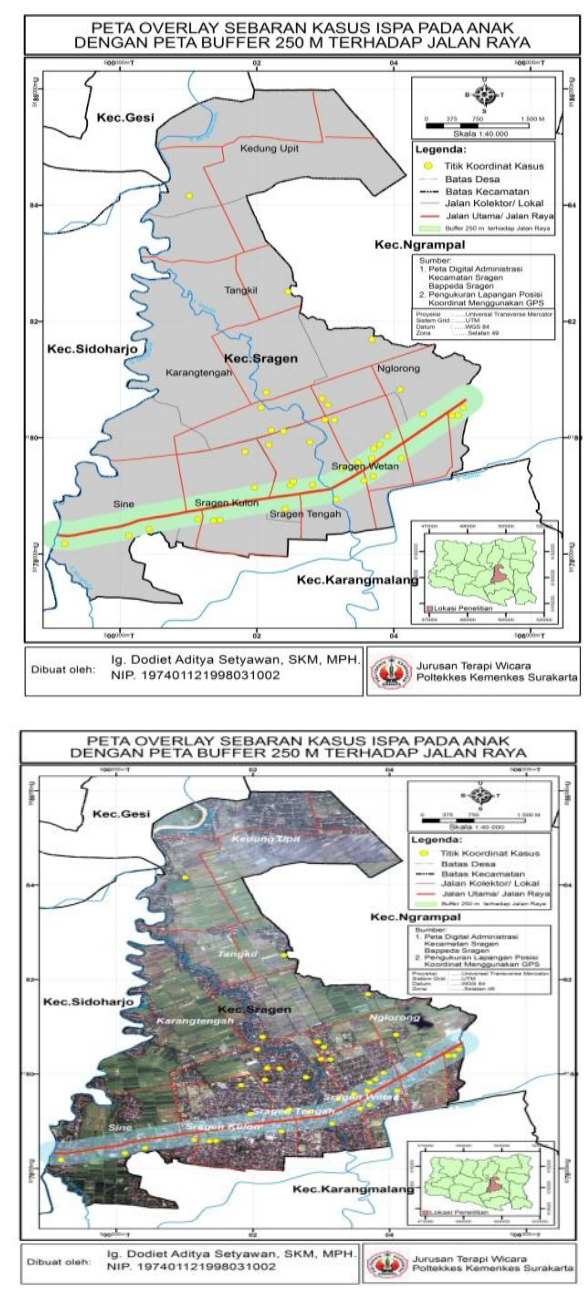

PEMBAHASAN

Berdasarkan hasil penelitian tersebut di atas menunjukkan bahwa Kejadian kasus ISPA pada anak di kecamatan Sragen tertinggi terjadi di 4 desa/kelurahan yang secara berturut- turut adalah kelurahan Sragen Wetan sebanyak 11 kasus, kelurahan Nglorog sebanyak 9 kasus, kelurahan Sragen Tengah sebanyak 7 kasus dan kelurahan Sragen Kulon sebanyak 5 kasus.

Apabila dilihat dari peta citra digital distribusi kasus ISPA yaitu pada gambar 1 di atas, nampak bahwa keempat kelurahan tersebut mempunyai permukiman atau bangunan yang padat dan berada dekat dengan jalan raya yang ramai. Berdasarkan data dari Dinas Perhubungan, Komunikasi dan Informatika Kabupaten Sragen (2013), menyebutkan bahwa volume lalulintas pada jalan raya tersebut, yaitu jalan Sukowati, tercatat rata-rata 2.085 kendaraan/jam dengan kecepatan ratarata $40 \mathrm{~km} / \mathrm{jam}$.

Dari jumlah tersebut, rata-rata jenis kendaraan yang melintas antara lain berupa sepeda motor dengan jumlah rata-rata 1.249 kendaraan/jam, mobil penumpang $662 \mathrm{kendaraan} / \mathrm{jam}$, truck 124 kendaraan/jam, dan bus sebanyak 50 kendaraan/jam.

Kondisi seperti ini dapat diasumsikan bahwa di wilayah tersebut kemungkinan tingkat polusi udaranya lebih tinggi dibandingkan dengan empat kelurahan yang lain yaitu desa Sine, Karangtengah, Tangkil maupun Kedung Upit yang permukimannya tidak tampak padat dan berada lebih jauh dari jalan raya.

Sebagaimana diketahui bahwa Polusi udara merupakan pencetus yang harus diperhatikan bagi anak yang rentan dengan penyakit gangguan pernapasan. Polusi ini bisa berada outdoor seperti di sekitar rumah, jalan raya, tempat kerja, dan sekolah, maupun indoor tempat tinggalnya. Polutan outdoor berasal dari asap pabrik, bengkel, pembakaran sisa atau sampah industri, aktifitas perdagangan dan 
perumahan serta gas buang yang berasal dari knalpot kendaraan bermotor (Mukono,2008). Polutan seperti sulfur dioksida $\left(\mathrm{SO}_{2}\right)$, ozon, dan nitrogen dioksida $\left(\mathrm{NO}_{2}\right)$, Carbon Monoksida (CO), dan partikulat debu dinyatakan sebagai pencetus terjadinya bronkokonstriksi, membuat saluran pernafasan lebih responsif, dan meningkatkan respon alergi. (Kurniawati, 2006).

Selanjutnya, Mulia (2005) juga menyatakan bahwa gangguan kesehatan pada manusia sebagai akibat dari pencemaran udara lebih sering terjadi pada saluran pernafasan dan organ penglihatan. Salah satu dampak kronis dari pencemaran udara terhadap penyakit saluran penafasan manusia diantaranya adalah ISPA, Asma, Bronchitis dan Emphysema.

Sebuah penelitian yang dilakukan di California Selatan oleh Mc.Connell, R. et al.(2010) memberikan hasil bahwa risiko penyakit gangguan pernapasan pada anak meningkat yang disebabkan oleh paparan polusi udara karena aktifitas lalulintas jalan yang mengandung polutan gas $\mathrm{NO}_{2}$ dengan $\mathrm{HR}=2.18,95 \% \mathrm{CI}=1.18-4.01$ Penelitian ini menunjukkan bahwa polusi udara terkait lalu lintas jalan di sekitar rumah dan sekolah dapat meningkatkan kejadian penyakit gangguan pernapasan pada anak-anak.

Berdasarkan hasil analisis bivariat dengan uji Chi Square pada Tabel 3 tersebut di atas, diperoleh nilai $p$ sebesar 0,000. Hal menunjukkan bahwa secara statistik terdapat hubungan yang bermakna antara kepadatan penghuni rumah dengan kejadian ISPA pada anak.

Sedangkan parameter kekuatan hubungan didapatkan nilai Odds Ratio (OR) sebesar 13.63 dengan Confidence Interval 95\% antara 3.60-51.55. Hal ini berarti bahwa anak yang tinggal dalam rumah dengan tingkat kepadatan penghuni rumah yang melebihi batas normal mempunyai kemungkinan 13.63 kali lebih besar untuk mengalami serangan ISPA dibandingkan dengan anak yang tinggal dalam rumah dengan tingkat kepadatan yang normal.

Tingkat kepadatan penghuni rumah dapat menjadi tolak ukur dari status sosial ekonomi keluarga. Dimana status sosioal-ekonomi pada suatu keluarga dapat mewakili karakteristik gaya hidup individu.

Hasil penelitian ini menunjukkan bahwa tingkat sosial ekonomi keluarga pada sebagian besar responden yaitu keluarga anak yang menderita ISPA di kecamatan Sragen dapat dikatakan mayoritas dalam kategori menengah kebawah, sehingga pemenuhan kebutuhan tempat tinggal belum tercukupi dengan baik yang terlihat dari prosentase responden yang tingkat kepadatan penghuni rumahnya tinggi yaitu terdapat $92,5 \%$.

Penelitian yang terkait dengan hubungan latar belakang sosial ekonomi dengan kejadian penyakit gangguan saluran pernapasan termasuh ISPA pada anak sudah pernah dilakukan oleh Lindbaek, et al pada tahun 2003 di Norwegia. Hasil penelitian tersebut menunjukkan bahwa faktor latar belakang sosial ekonomi yang paling mempengaruhi terjadinya penyakit gangguan pernapasan diantaranya adalah faktor psikososial, kebiasaan dalam pola makan, orang tua dengan penyakit kronis, jumlah anak dan jumlah kamar dalam rumah.

Penelitian tersebut menyimpulkan bahwa terdapat hubungan antara faktor sosial ekonomi dengan penyakit gangguan pernapasan termasuk ISPA 
pada anak-anak, di samping faktorfaktor risiko lain yang diketahui.

Berdasarkan hasil analisis bivariat dengan uji Chi Square pada Tabel 3 di atas, diperoleh nilai $p$ sebesar 0,014 . Hal tersebut menunjukkan bahwa secara statistik terdapat hubungan yang bermakna antara jarak tempat tinggal dengan jalan raya dengan kejadian ISPA pada anak di kecamatan Sragen.

Sedangkan parameter kekuatan hubungan didapatkan nilai Odds Ratio (OR) sebesar 3.09 dengan Confidence Interval $95 \%$ antara $1.24-7.70$. Hal ini berarti bahwa anak yang rumahnya dekat dengan jalan raya mempunyai kemungkinan 3.09 kali lebih besar untuk mengalami serangan ISPA dibandingkan dengan anak yang tempat tinggalnya jauh dengan jalan raya.

Hasil penelitian ini sesuai dengan penelitian yang dilakukan di California Selatan oleh McConnell, R. et al.(2010) yang menunjukkan bahwa polusi udara oleh polutan NO2 terkait lalu lintas jalan raya di sekitar rumah dapat meningkatkan kejadian penyakit gangguan saluran pernapasan termasukISPA pada anak-anak dengan $\mathrm{HR}=2.18,95 \% \mathrm{CI}=1.18-4.01$.

Selanjutnya Nuvolone et al. (2011) dalam penelitiannya di Italia juga menunjukkan hasil yang sama. Penelitian ini menginformasikan potensi dampak dari polusi udara terkait lalu lintas jalan raya (main road) terhadap status kesehatan pernapasan yang didasarkan pada jarak tempat tinggal responden dengan jalan raya yang diklasifikasikan melalui fungsi overlay dan buffering dengan Geographical Information Syatem (GIS). Dalam penelitian tersebut menunjukkan bahwa subyek yang bertempat tinggal dengan jarak antara 100-250 meter dari jalan raya (main road), mempunyai risiko untuk mengalami gangguan atau penyakit pernapasan yang diantaranya adalah Dyspnea $(\mathrm{OR}=1.61,95 \% \mathrm{CI}=$ $1.13-2.28)$, COPD (OR $=1.21,95 \%$ $\mathrm{CI}=0.69-2.13)$, dan Asthma $(\mathrm{OR}=$ $1.55,95 \% \mathrm{CI}=0.83-2.87)$.

Sebagaimana diketahui bahwa polusi udara merupakan pencetus yang harus diperhatikan bagi penderita asma. Polusi ini bisa berada outdoor seperti di sekitar rumah, jalan raya, tempat kerja, dan sekolah, maupun indoor tempat tinggalnya. Polutan outdoor berasal dari asap pabrik, bengkel, pembakaran sisa atau sampah industri, aktifitas perdagangan dan perumahan serta gas buang yang berasal dari knalpot kendaraan bermotor. Polutan seperti sulfur dioksida (SO2), ozon, dan nitrogen dioksida (NO2), Carbon Monoksida (CO), dan partikulat debu dinyatakan sebagai pencetus terjadinya bronkokonstriksi, membuat saluran pernafasan lebih responsif, dan meningkatkan respon alergi.

Hal serupa juga disampaikan oleh Mulia (2005) yang secara khusus juga menyebutkan bahwa akibat pencemaran udara dari kendaraan bermotor, saat ini tercatat bahwa penyakit Infeksi Saluran Pernafasan Akut (ISPA) dan bahkan gangguan pernafasan lain selalu menduduki peringkat atas dari laporan kejadian penyakit di pusat-pusat pelayanan kesehatan seperti Puskesmas, Klinik maupun Rumah Sakit.

\section{KESIMPULAN DAN SARAN}

Dari hasil penelitian dan pembahasan tersebut dapat disimpulkan bahwa Pemodelan Sistem Informasi Geografis (SIG) dengan pendekatan analisis spasial merupakan cara yang mudah dipahami dan dapat dengan jelas menggambarkan distribusi penyakit ISPA pada anak di kecamatan Sragen. 
Faktor-faktor risiko yang terbukti secara signifikan berhubungan dengan kejadian penyakit ISPA pada anak di kecamatan Sragen adalah Kepadatan Penghuni Rumah $(\mathrm{OR}=0.075,95 \% \mathrm{CI}$ $=0.019-0.293$, dengan nilai $\mathrm{p}=$ 0.000); dan Jarak Tempat Tinggal yang Dekat dengan Jalan Raya yaitu dalam Radius $\leq 250$ Meter $(\mathrm{OR}=0.334,95 \%$ $\mathrm{CI}=0.118-0.949$, dengan nilai $\mathrm{p}=$ 0.040).

Sedangkan faktor risiko yang terbukti paling dominan berhubungan kejadian penyakit ISPA pada anak di kecamatan Sragen adalah jarak tempat tinggal dengan jalan raya dalam radius $\leq$ 250 meter dengan $\mathrm{OR}=0.334,95 \% \mathrm{CI}$ $=0.118-0.949$, dengan nilai $\mathrm{p}=0.040$.

Saran yang dapat disampaikan dari hasil penelitian ini adalah Puskesmas kecamatan Sragen bekerja sama dengan Dinas Kesehatan Kabupaten Sragen hendaknya mulai mengembangkan aplikasi Sistem Informasi Geografis (SIG) untuk pemantauan, pengendalian dan pencegahan terhadap terjadinya kasus ISPA khususnya pada anak-anak.

Selanjutnya perlu adanya sinergi dan kerja sama linas sektoral antara Dinas Kesehatan Kabupaten Sragen dengan Dinas-dinas terkait seperti Dinas Perhubungan, Komunikasi dan Informatika, Dinas Pekerjaan Umum dan Badan Lingkungan Hidup dalam upaya pengelolaan lingkungan disekitar jalan raya untuk meminimalkan kadar polusi udara akibat aktivitas kendaraan bermotor dengan penanaman pohon disekitar jalan raya, serta semakin memperbanyak jalur hijau.

\section{DAFTAR RUJUKAN}

McConnell, R., Islam, T., Shankardass, K., Jerrett, M., Lurmann, F., Gilliland, F., et al., (2010). Childhood Incident Asthma and Traffic-Related Air Pollution at Home and School. Environmental Health. Available at: http://www.ncbi.nlm.nih.gov/p mc/articles/PMC2920902/

Mulia, M.R., (2005). Kesehatan Lingkungan. Edisi Revisi. Penerbit Graha Ilmu. Yogyakarta.

Nuvolone, D., Maggiore, R. D., Maio, S., Fresco, R., Baldacci, S., Carrozzi, L., et al., 2011. Geographical information systems and environmental epidemiology: a cross-sectional spatial analysis of the effects of traffic-related air pollution on population respiratory health. Environmental health : a global access science source, 10(1), p.12. Available at: http://www.ncbi.nlm.nih.gov/pu bmed/21362158. Diakses pada tanggal 16 Januari 2014.

Setyawan, D.A., 2013. Analisis Spasial Faktor-faktor Risiko Kejadian Asma Bronkial pada Anak di Kecamatan Sragen Kabupaten Sragen. Tesis. Program Pasca Sarjana Fakultas Kedokteran Universitas Gadjah Mada Yogyakarta. 